\title{
ВЕДЕНИЕ ФИНАНСОВОЙ СТАТИСТИКИ ВНЕШНЕЙ ТОРГОВЛИ РОССИЙСКОЙ ФЕДЕРАЦИИ В УСЛОВИЯХ ФУНКЦИОНИРОВАНИЯ ЕАЭС
}

\begin{abstract}
АннОТАЦия. В современных условиях развития интеграционных объединений немаловажное значение имеет как взаимная, так и внешняя торговля. Динамика внешней торговли стран Евразийского экономического союза (далее - ЕАЭС) приведена на основе данных Евразийской экономической комиссии. В процессе анализа не учитывалось появление новых членов в ЕАЭС Республики Армения и Республики Кыргызстан, поскольку внешнеторговые показатели этих стран на данном этапе для интеграционного объединения незначительны. Состояние внешних торговых связей - один из основных показателей динамики интеграционных процессов на таможенной территории ЕАЭС. Сегодня важной задачей во внешнеторговой сфере является вопрос разработки и применения унифицированных условий, при которых будет урегулирован товарообмен со странами, не входящими в ЕАЭС. Автором анализируется таможенно-финансовая статистика, которая служит механизмом оценивания хода развития интеграционного объединения в области внешнеторговых связей, в том числе внешнеторговой политики.

кЛючевЫЕ СЛовА. Федеральный бюджет; внешняя торговля России; Евразийский экоНомический союз.

ИНФОРМАЦИЯ О СТАТЬЕ. Дата поступления 11 сентября 2017 г.; дата принятия к печати 19 декабря 2017 г.; дата онлайн-размещения 29 декабря 2017 г.
\end{abstract}

M. V. Dubinin

Baikal State University, Irkutsk, Russian Federation

\section{MAINTAINING FINANCIAL FOREIGN TRADE STATISTICS OF THE RUSSIAN FEDERATION IN TERMS OF THE EAEU FUNCTIONING}

\begin{abstract}
The mutual and foreign trade has a great importance in the current context of developing integration associations. The article presents the foreign trade dynamics of the countries of the Eurasian Economic Union (hereinafter the EAEU) that is based on the data of the Eurasian Economic Commission. The analysis does not take into account the appearance of new members in the EAEU (the Republic of Armenia and the Republic of Kyrgyzstan), since the foreign trade indicators of these countries are insignificant for the integration association at this stage. The state of foreign trade relations is one of the main indicators for the integration processe dynamics on the customs territory of the EAEC. The development and application issues of unified conditions under which the commodity exchange with non-EAEU countries would be regulated are an important problem in the foreign trade sphere nowadays. The author analyzes the customs and financial statistics that functions as a mechanism for assessing the development of integration association in the field of foreign trade relations, including foreign trade policy.

KEYWORDS. Federal budget; foreign trade of Russia; Eurasian Economic Union.

ARTICLE INFO. Received September 11, 2017; accepted December 19, 2017; available online December 29, 2017.
\end{abstract}

Отдельного внимания заслуживает вопрос осуществления сотрудничества ЕАЭС с международными организациями и интеграционными объединениями. $\mathrm{K}$ таким партнерским международным интеграционным объединениям, с которыми

(C) М. В. Дубинин, 2017

\section{Baikal Research Journal}

электронный научный журнал Байкальского государственного университета 
существуют перспективы развития взаимовыгодного сотрудничества, можно отнести Общий рынок стран Южной Америки (далее - МЕРКОСУР) и Ассоциацию государств Юго-Восточной Азии (далее - ACEAH) [1]. Кроме того, важно учитывать также и возможности установления постоянных внешнеторговых связей с Советом сотрудничества арабских государств Персидского залива.

Сотрудничество с перечисленными партнерами формализуется путем подписания меморандумов о взаимопонимании, что сделает возможным дальнейшее развитие постоянных диалогов по торгово-экономическим вопросам ${ }^{1}$. Такое развитие событий откроет возможности эффективного продвижения интересов бизнеса евразийской интеграции на внешних рынках, международных площадках для пополнения баз деловых контактов, а также развития и укрепления взаимовыгодного сотрудничества.

На сегодняшний день значимым интеграционным объединением, с которым активно сотрудничает ЕАЭС, является Европейский союз (далее - ЕС) [2]. Торговля с этой интеграцией уже на данном этапе развития отношений осуществляется с применением комплексного подхода - сотрудничество осуществляется одновременно на уровне наднациональных институтов, а также с отдельными органами власти любого из членов ЕС. Немаловажным является тот факт, что к развитию партнерских отношений со странами-участницами ЕАЭС большой интерес проявили государства-члены Тихоокеанского Альянса, Республика Чили, а также Южно-Африканская Республика. Республика Чили и страны-участницы ЕАЭС на внешних рынках в большей степени являются партнерами, а не конкурентами, что открывает большие возможности для укрепления взаимовыгодных отношений ${ }^{2}$.

На сегодняшний момент наблюдается весомый потенциал сотрудничества стран евразийской интеграции с государствами Латинской Америки, который на данный момент реализуется лишь отчасти. Кроме того, опыт ЕАЭС также весьма интересен Южно-Африканской Республике, в силу того, что ЮАР входит в состав Южноафриканского таможенного союза, а также принимает активное участие в интеграционных процессах, проходящих на Африканском континенте.

Основными приоритетами наднациональных органов ЕАЭС во всех направлениях сотрудничества с международными интеграциями являются защита и продвижение деловых интересов ЕАЭС, способствование экономическому росту и развитию участников евразийской интеграции. Ставя перед собой целью соблюдение указанных приоритетов, Евразийская экономическая комиссия (далее - ЕЭК) обеспечивает публичность указанного процесса, исходит из необходимости предоставления возможности бизнесу, та также деловым ассоциациям быть участником соответствующей работы на всех этапах, начиная выбором внешнего делового партнера и направления взаимовыгодного взаимодействия и заканчивая отдельными международными мероприятиями.

Основные показатели, используемые при оценке эффективности функционирования интеграционных объединений, - это показатели изменения объемов внешней торговли участников ЕАЭС [3]. Ниже приведены данные ЕАЭС, уточненные в период 2011-2016 года, характеризующие состояние внешней торговли государств-членов ЕАЭС.

В 2012 году объем внешней торговли государств-членов ЕАЭС составил 934,6 млрд дол. США, что на 3 \% . больше показателей 2011 года. В 2013 году объем торговли в текущих ценах понизился до 933 млрд дол. США или на 0,8 \%. В

1 Таможенный кодекс Таможенного союза [Электронный ресурс] : федер. закон РФ от 27 нояб. 2009 г. № 17-ФЗ : (в ред. от 8 мая 2015) // СПС «КонсультантПлюс».

${ }^{2}$ Федеральная таможенная служба : офиц. сайт. URL: http://www.customs.ru/ (дата обращения: 7 авг. 2017 г.).

\section{Baikal Research Journal}

электронный научный журнал Байкальского государственного университета 
2014 году стоимостный объем упал до 869 млрд дол. США (на 6,9 \% ). В 2015 году стоимостный объем упал до 579 млрд дол. США (на 33,3 \%). Также снижение объемов внешней торговли наблюдалось и в 2016 году, стоимостный объем упал до 509 млрд дол. США (на $12,1 \%$ ) (рис. 1).

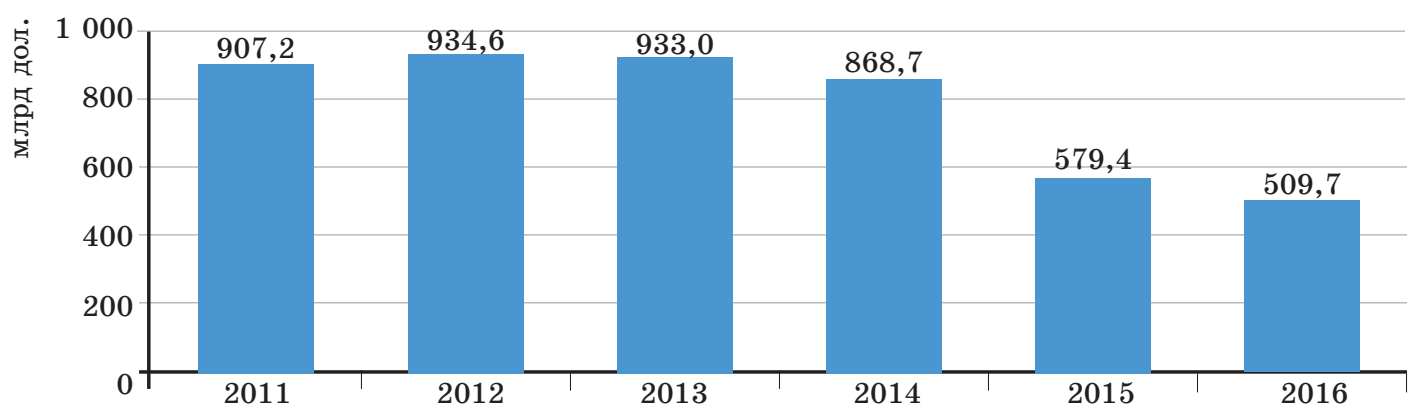

Рис 1. Внешняя торговля государств-членов ЕАЭС в 2011-2016 г2.

Таким образом, общие данные внешней торговли стран-участников ЕАЭС показывают сокращение объемов торговли с третьими странами [4]. Впрочем, при анализе данных такого рода, безусловно, учитывается общая макроэкономическая ситуация - спад объемов ВВП России, Казахстана, Беларуси, Армении, Кыргызстана, тяжелую ситуацию с валютным курсом и другие факторы, препятствующие развитию торговли с третьими странами. Следует отметить, что во внешней торговле наибольший вклад в формирование объема внешней торговли интеграционного объединения вносит Российская Федерация (рис. 2).

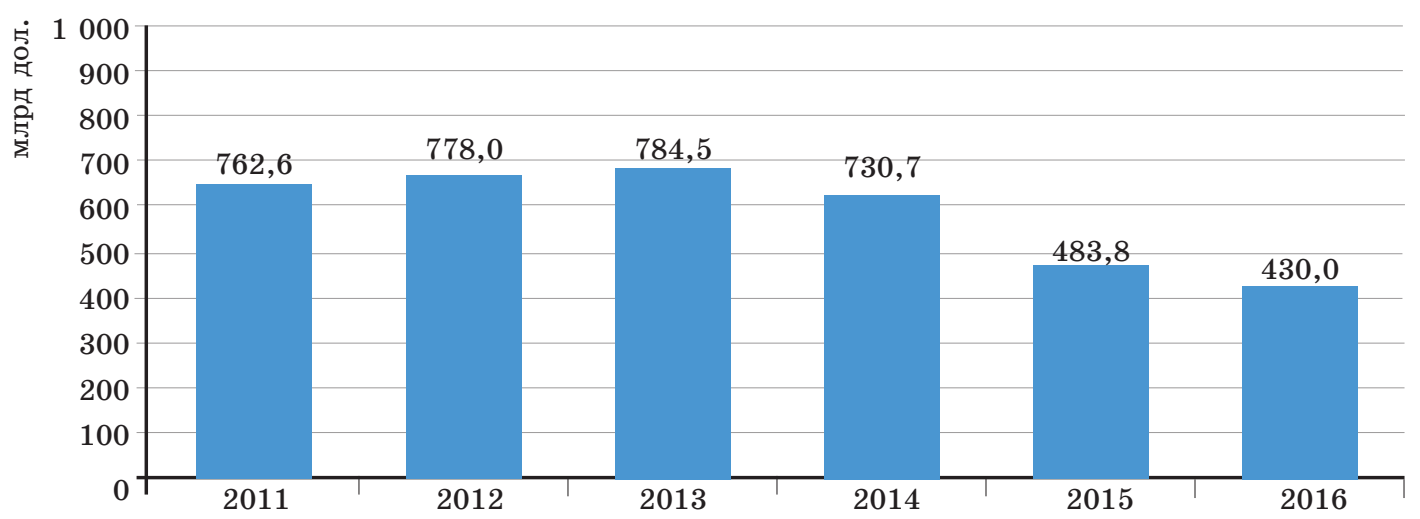

Рис 2. Внешняя торговля товарали России со всеми странами

Внешняя торговля Российской Федерации снизилась с 762,6 млрд дол. США в 2011 г. до 430 млрд дол. США в 2016 году. При этом своего максимума (в рассматриваемом временном периоде) она достигла в 2013 году и составила 784,5 млрд дол. США. В первую очередь, это произошло за счет роста стоимостного объема экспорта товаров из России в третьи страны.

Одним из основных торговых партнеров Российской Федерации по-прежнему является Китай [5]. Несмотря на сокращение поставок каменного угля, вызванное снижением спроса в начале 2016 года, Россия увеличила объемы внешней торговли

\section{Baikal Research Journal}


с Китаем до 66,1 млрд дол. США. Другими словами, повысила показатели в сравнении с предыдущим годом на $4 \%$. Импортеры из Китая увеличили объем закупок следующих товаров: машины, оборудование, автомобили, металлы, продовольственные товары, в том числе фрукты и овощи, колбасы, хлеб, шоколад и другие продукты. Кроме того, летом 2016 года расширилось партнерство в новых сферах, когда Россия заключила Китаем свыше 30 многообразных соглашений.

Внешнеторговые обороты со странами Европы, наоборот, снизились. Показатели торговли с Италией уменьшились на $35 \%$ до 19,8 млрд дол. США, с Нидерландами на $17 \%$ до 32,3 млрд дол. США, с Германией на 11,1 \% до 40,7 млрд дол. США. Исключением стала Франция, с ней торговля выросла за счет увеличения поставок зерновых и газа на $14 \%$ до 13,3 млрд дол. США ${ }^{3}$. В свою очередь на 32 \% снизился объем взаимной торговли с Турцией, что стало результатом торговых ограничений, и составил только 15,8 млрд дол. США [6]. В результате политической напряженности и запретов резко упали поставки турецкого текстиля, овощей и фруктов.

Помимо перечисленных выше внешних связей, с осени 2016 года действует Соглашение о создании зоны свободной торговли евразийской интеграции с Вьетнамом, которое предполагает, что 59 \% всех товарных позиций не будут облагаться таможенной пошлиной [7]. Диверсификация российского экспорта и наращивание вывоза продукции с высокой степенью обработки будет связана с реструктуризацией промышленности и развитием ее конкурентоспособности на мировом рынке производств ${ }^{4}$.

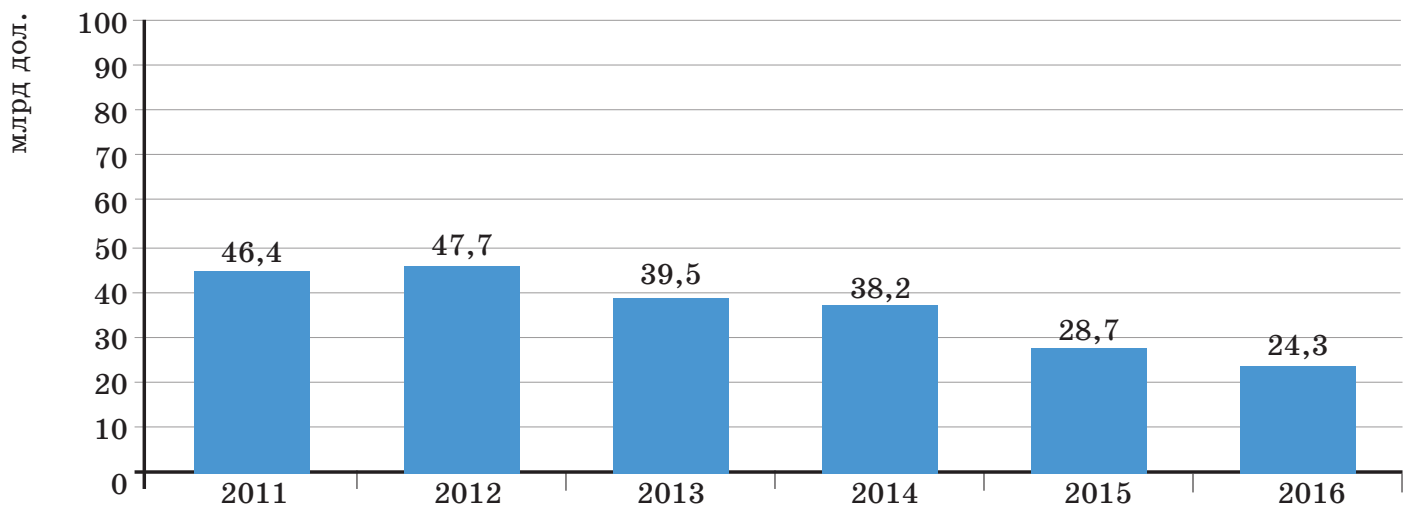

Рис 3. Внешняя торговля товарами Беларуси со всели странами

Внешнеторговые обороты Республики Беларусь снизились с 46,4 млрд. долл. США (показатели 2011 года) до 24,3 млрд дол. США в 2016 году. Максимальный объем внешней торговли был достигнут в 2012 году, и составил 47,7 млрд дол. США. Ключевой проблемой во внешней торговле Республики Беларусь является постепенно увеличивающееся отрицательное сальдо внешней торговли товарами, которое в период с 2012 года по 2016 год увеличилось в 14 раз. Основными причинами являются низкая эффективность внешней торговли, недостаточная рентабельность экспорта, слабая конкурентоспособность отечественных товаров.

\footnotetext{
${ }^{3}$ Регионы России. Социально-экономические показатели. 2016. URL: http://www.gks.ru/wps/ wcm/ connect/rosstat_main/rosstat/ru/statistics/publications/catalog/doc_1138-623506156 (дата обращения: 8 авг. 2017 г.)

${ }^{4}$ Организация стран-экспортеров нефти. URL: http://fb.ru/article/161077/opek-rasshifrovka-ifunktsii-organizatsii-spisok-stran---chlenov-opek (дата обращения: 10 авг. 2017 г.).
}

\section{Baikal Research Journal}


На сегодняшний день Республика Беларусь поддерживает внешнеторговые связи более чем со 180 странами мира. Европейские страны, которые поддерживают наиболее развитые торговые и экономические связи с Беларусью, перечислены в этом списке: Великобритания, Нидерланды, Германия, Польша, Латвия, Литва, Италия, Бельгия и др. Среди стран СНГ, после России, второе место занимает Украина, а третье - Казахстан ${ }^{5}$.

Основным экспортером Республики Беларусь является Россия, ее доля занимает 46,2 \% белорусского экспорта. Главными экспортными группами для республики являются: продукция нефтехимического комплекса: нефтепродукты, химические волокна, шины; калийные и азотные удобрения; металлопродукция; сельскохозяйственная и грузовая техника; мясомолочная продукция; сахар и другая продукция агропромышленного комплекса ${ }^{6}$.

В Республике Казахстан внешнеторговые обороты также снизились с показателей 2011 года - 98,2 млрд дол. США до самых низких за последние годы показателей 2016 года $-48,4$ млрд дол. США. Максимум товарооборота в рассматриваемом временном периоде был достигнут в 2012-2013 годах 108,9 млрд дол. США (рис. 4).

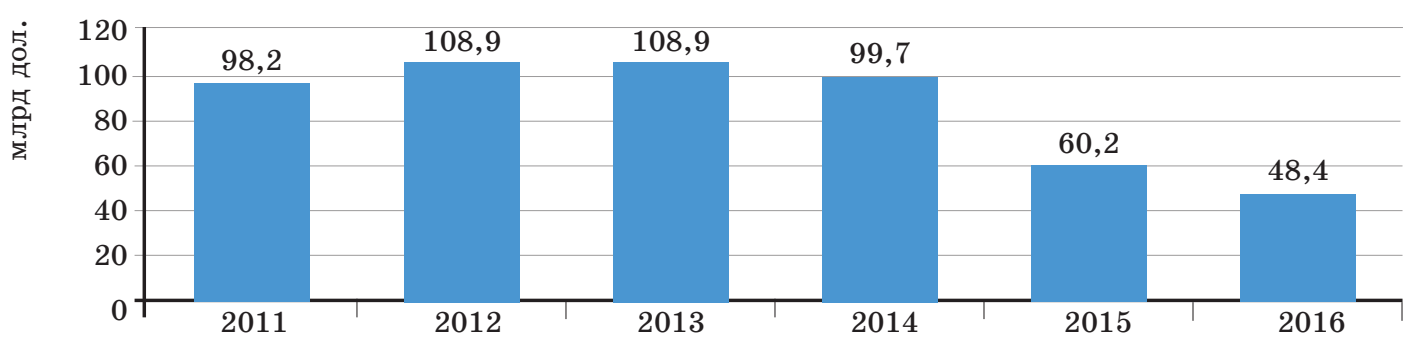

Рис 4. Внешняя торговля товарами Беларуси со всеми странами

Неблагоприятное влияние на финансово-экономическое состояние экономики Казахстана также оказывают такие факторы, как: уменьшение объемов добычи нефти в стране, продолжающийся застой в экономике РФ, задержка темпов экономического роста в КНР и ряде западных государств, а также изменчивость курсов главных валют [8].

Главной причиной снижения внешней торговли для всех трех стран стала сниженная стоимость нефти, которая обусловлена избыточным предложением на мировом рынке нефти, возникшим в результате наращивания темпов добычи этого природного ресурса странами ОПЕК. Цена за баррель нефти резко опустилась ниже многолетних минимумов [9]. Это не могло не отразиться на стоимостных объемах вывоза нефти, и на снижении доходов российского федерального бюджета. Резкое падение цен на нефть стало причиной сильнейшей девальвации рубля. Показатели курса отечественной денежной единицы в декабре 2016 года относительно дол. США превысили отметку в 60 рублей, а к евро - 70 рублей. Возросшие цены в иностранной валюте обусловили уменьшение объемов ввоза товаров, заметно снизился спрос на большой перечень зарубежных товаров, сырья и услуги иностранных компаний.

Еще одним, обвал курса рубля привел к тому, что российские производители, стремясь получить более выгодную экспортную выручку в иностранной валюте, пе-

${ }^{5}$ Евразийская экономическая комиссия. URL: http://www.eurasiancommission.org/ru. (дата обращения: 2 авг. 2017 г.).

${ }^{6}$ Внешняя торговля Республики Беларусь. URL: http://myfin.by. (дата обращения: 13 авг. 2017 г.).

\section{Baikal Research Journal}


реориентировались на мировые рынки [10]. Основными рынками сбыта отечественных товаров стали страны дальнего зарубежья, а не страны СНГ. Такой перекос в пользу стран дальнего зарубежья объясняется тем, что в странах СНГ, так же как и в России, наблюдались экономические проблемы. Российская продукция на зарубежных рынках пользовалась высоким спросом, поскольку их стоимость по сравнению с аналогичными товарами других мировых производителей была заметно ниже.

В качестве объективных причин снижения показателей внешней торговли, можно отметить также нестабильную общую мировую конъюнктуру, темпы инфляции, политические противоречия с лидерами развитых стран, взаимные экономические санкции, новые условия хозяйствования: высокие банковские процентные ставки, валютный курс [9]

Дальнейший анализ внешней торговли ЕАЭС подразумевает отдельное изучение экспортных операций ЕАЭС на уровне укрупненных групп товаров для последующего анализа (по странам ЕАЭС доли внешней торговли изображены на рис. 5).

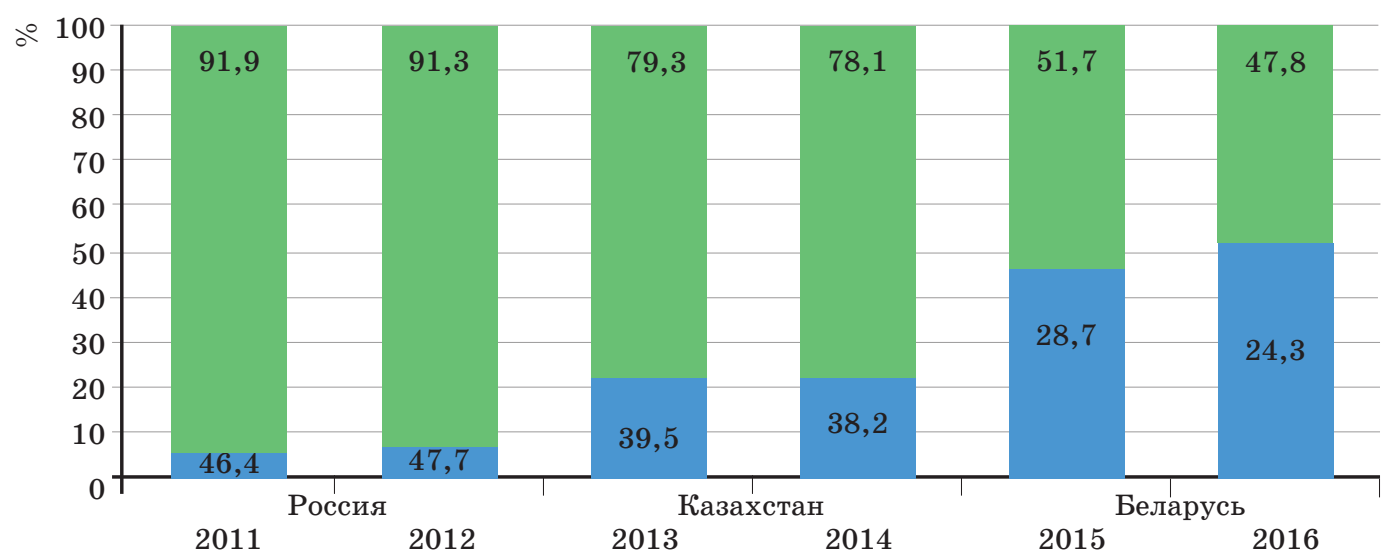

Удельный вес взаимной торговли в общем объеме внешней торговли

Удельный вес торговли с третьими странами в общем объеме внешней торговли

Рис 5. Удельный вес взаимной и внешней торговли России, Казахстана и Беларуси

Наибольший спад адвалорного объема поставок наблюдался в товарной линии минеральных продуктов на 28746,9 млн дол. США или на $6,6 \%$. В стоимостном выражении существенно меньше (на 1524,8 млн дол. США или на 9,9\%) поставлено на внешний рынок машин, оборудования и транспортных средств, а также металлов и изделий из них (563,9 млн дол. США или на $1,3 \%)$, что в обоих случаях объясняется снижением цен и экономической ситуацией в странах ЕАЭС (табл. 1).

Таблица 1

Внешняя торговля по укрупненным группам товаров государств-членов ЕАЭС за 2011-2016 22 .

\begin{tabular}{|c|c|c|c|c|c|c|c|}
\hline \multirow{2}{*}{$\begin{array}{c}\text { Код и наименование } \\
\text { укрупненной группы товаров }\end{array}$} & \multicolumn{6}{|c|}{ Стоимость, млн дол. США } \\
\cline { 2 - 8 } & 2011 & 2012 & 2013 & 2014 & 2015 & 2016 \\
\hline \multirow{2}{*}{$01-24$} & 437184,5 & 581397,4 & 593661,8 & 587667,9 & 555617,9 & 509789,5 \\
\cline { 2 - 8 } & $\begin{array}{l}\text { Псего } \\
\text { Продох: } \\
\text { товары и сельскохо- } \\
\text { зяйственное сырье }\end{array}$ & 9897 & 13563,3 & 18348,9 & 16902,7 & 18887,0 & 16941,1 \\
\hline
\end{tabular}

\section{Baikal Research Journal}


Окончание табл. 1

\begin{tabular}{|c|l|r|r|r|r|r|r|}
\hline \multicolumn{2}{|c|}{$\begin{array}{c}\text { Код и наименование } \\
\text { укрупненной группы товаров }\end{array}$} & \multicolumn{6}{|c|}{ Стоимость, млн дол. США } \\
\cline { 2 - 8 } $25-27$ & Минеральные продукты & 307820,2 & 423899,4 & 432014,6 & 435988,8 & 407241,9 & 390055,6 \\
\hline $28-40$ & $\begin{array}{l}\text { Продукция химиче- } \\
\text { ской промышленности }\end{array}$ & 22534,9 & 32912,7 & 33879,3 & 27947,8 & 27785,0 & 20583,9 \\
\hline $41-43$ & $\begin{array}{l}\text { Кожевенное сырье, } \\
\text { пушнина и изделия } \\
\text { из них }\end{array}$ & 364,3 & 416,7 & 525,5 & 661,9 & 444,2 & 530,5 \\
\hline $44-49$ & $\begin{array}{l}\text { Древесина и цел- } \\
\text { люлозно-бумажные } \\
\text { изделия }\end{array}$ & 9387,4 & 10886,3 & 10279,9 & 10675,0 & 11161,1 & 9865,1 \\
\hline $50-67$ & $\begin{array}{l}\text { Текстиль, текстиль- } \\
\text { ные изделия и обувь }\end{array}$ & 921,2 & 1020,9 & 907,3 & 973,6 & 942,8 & 837,8 \\
\hline $72-83$ & $\begin{array}{l}\text { Металлы и изделия } \\
\text { из них }\end{array}$ & 46465,3 & 51886,4 & 48475,3 & 43357,2 & 42793,3 & 32279,1 \\
\hline $84-87$, & $\begin{array}{l}\text { Машины, оборудова- } \\
\text { ние и транспортные } \\
\text { средства }\end{array}$ & 12096,3 & 14145,9 & 14503,4 & 15283,6 & 13758,8 & 13007,3 \\
\hline
\end{tabular}

Источник: составлено автором на основе анализа ЕАЭС.

Анализ данных внешней торговли в 2011-2016 гг. по укрупненным товарным группам ТН ВЭД ЕАЭС показал, что товарная структура экспорта во внешней торговле ЕАЭС имеет ярко выраженную сырьевую направленность. Основной экспорт составляют: металлы и изделия из них; минеральные продукты; продовольственные товары и сырье для их производства. За 2012 г. по сравнению с 2011 г. в товарной структуре экспорта на внешний рынок странами ЕАЭС наблюдается увеличение стоимостных объемов по укрупненным группам товаров «01-24: Продовольственные товары и сельскохозяйственное сырье» на $37 \%$; «25-27: Минеральные продукты» на 38 \% «28-40: Продукция химической промышленности» на $46 \%$; «41-43: Кожевенное сырье, пушнина и изделия из них» на 14,2 \%; «44-49: Древесина и целлюлозно-бумажные изделия» на $16 \%$; «50-67: Текстиль, текстильные изделия и обувь» на $11 \%$; «72-83: Металлы и изделия из них» на $12 \%$; «84-87, 90: Машины, оборудование и транспортные средства» на $17 \%$. За 2016 г. по сравнению с 2015 г. в товарной структуре экспорта на внешний рынок странами ЕАЭС наблюдается снижение стоимостных объемов по укрупненным группам товаров «25-27: Минеральные продукты» на $6,6 \%$; «1-43: Кожевенное сырье, пушнина и изделия из них» на $32,9 \%$; «84-87, 90: Машины, оборудование и транспортные средства» на $9,9 \%$. Можно констатировать предсказуемый (естественный) баланс роста объемов одних товаров и снижения объемов других товаров [11].

В 2016 г. при общем снижении внешней торговли на 32,8 \%, по всем разделам также произошло снижение объемов их продажи (табл. 2).

Таблица 2

Сведения о доли 4 групп с наибольшил спадол экспорта во внешней торговле в 2015-2016 22. (2руппы ТН ВЭД ЕАЭС, которые илели спад 0,5\% и более)

\begin{tabular}{|c|r|c|}
\hline Год & Количество групп с наибольшим спадом & $\begin{array}{c}\text { Доля групп с наибольшим спадом } \\
\text { во всем спаде, \% }\end{array}$ \\
\hline 2016 & 4 & 38,8 \\
\hline
\end{tabular}

Источник: составлено автором на основе анализа ЕАЭС.

Анализ показал, что небольшое количество групп, по каждой из которых спад составлял около 0,5 \% (и более) от общего спада по всем группам, в значительной

\section{Baikal Research Journal}


степени определяло суммарный спад и, таким образом, снижало рост внешней торговли. Общая доля спада таких товаров в суммарном весе снижения внешней торговли по всем товарам, по которым зафиксирован спад, составляла 71,3 \% (см. графу 3). Следует отметить, что 38,8 \% от объема сокращения внешней торговли в целом в 2016 г. приходится на 4 группы с наибольшими объемами падения (в сумме 169648,6 млн дол. США) внешней торговли (табл. 3)

Таблица 3.

Роль 4 групп, обусловивших основной спад объемов внешней торговли в 2016 г. в сравнении с 2015 2.

\begin{tabular}{|c|c|r|r|r|r|r|}
\hline \multirow{2}{*}{$\begin{array}{c}\text { № } \\
\text { п/п }\end{array}$} & \multirow{2}{*}{ ТН ВЭД ЕАЭС } & \multicolumn{2}{|c|}{ Объем взаимной торговли, млн дол. США } & \multicolumn{2}{|c|}{5 групп } \\
\cline { 2 - 7 } & \multicolumn{1}{|c|}{2014} & \multicolumn{1}{c|}{2015} & \multicolumn{1}{c|}{ изменение } & изменение, \% & \% ко всему спаду \\
\hline А & Б & \multicolumn{1}{c|}{2} & \multicolumn{1}{c|}{3} & 5 & 6 \\
\hline & Всего & 556800,3 & 373908,9 & $-182891,4$ & $-32,8$ & 100 \\
\hline & $\begin{array}{c}\text { Всего } \\
(4 \text { групп): }\end{array}$ & 436235,5 & 266586,9 & $-169648,6$ & $-38,8$ & 16,4 \\
\hline 1 & 27 & 402884,5 & 241615,9 & $-161268,6$ & $-40,0$ & 11,8 \\
\hline 2 & 72 & 21540,9 & 16403,7 & $-5137,2$ & $-23,8$ & 1,1 \\
\hline 3 & 84 & 7933,1 & 6012,2 & $-1920,9$ & $-24,2$ & 0,7 \\
\hline 4 & 85 & 3817 & 2555,1 & $-1261,9$ & $-33,1$ & \\
\hline
\end{tabular}

Источник: составлено автором на основе анализа ЕАЭС.

При этом спад внешней торговли по каждой из этих групп произошел по всем направлениям торговли (см. табл. 4).

Таблица 4

\begin{tabular}{|c|c|c|c|c|}
\hline \multicolumn{5}{|c|}{2014} \\
\hline \multirow{2}{*}{$\begin{array}{l}\text { № } \\
\Pi / \Pi\end{array}$} & \multirow{2}{*}{$\begin{array}{c}\text { TH ВЭД ЕАЭС } \\
\text { (группа) }\end{array}$} & \multicolumn{2}{|r|}{ Казахстан } & \multirow{2}{*}{$\begin{array}{c}\text { Россия } \\
\text { РФ -> вне ЕАЭС }\end{array}$} \\
\hline & & РБ -> вне ЕАЭС & РК -> вне ЕАЭС & \\
\hline 1 & $27^{8}$ & 10877,9 & 59626,9 & 332379,7 \\
\hline 2 & $72^{9}$ & 732,4 & 2347,9 & 18460 \\
\hline 3 & $84^{10}$ & 279,8 & 223,8 & 7489,5 \\
\hline 4 & $85^{11}$ & 167,9 & 190,9 & 3458,2 \\
\hline \multicolumn{5}{|c|}{2015} \\
\hline 1 & 27 & 7248,5 & 29960,4 & 204407,1 \\
\hline 2 & 72 & 656,1 & 1968,4 & 13697,2 \\
\hline 3 & 84 & 204,4 & 108,2 & 5657,5 \\
\hline 4 & 85 & 132,9 & 109,9 & 2286,8 \\
\hline \multicolumn{5}{|c|}{ Падение внешней торговли } \\
\hline 1 & 27 & $-3629,4-$ & $-29666,5$ & $-127972,6$ \\
\hline 2 & 72 & $-76,3$ & $-379,5$ & $-4762,8$ \\
\hline 3 & 84 & $-75,4$ & $-115,6$ & -1832 \\
\hline 4 & 85 & -35 & -81 & $-1171,4$ \\
\hline
\end{tabular}

${ }^{7}$ Федеральное казначейство Российской Федерации: офиц. сайт. URL: http://www.roskazna.ru/ ispolnenie-byudzhetov/federalnyj-byudzhet (дата обращения: 28 июля 2017 г.).

${ }_{8}^{8}$ Топливо минеральное, нефть и продукты их перегонки; битуминозные вещества; воски минеральные.

${ }^{9}$ Черные металлы.

10 Реакторы ядерные, котлы, оборудование и механические устройства; их части.

11 Электрические машины и оборудование, их части; звукозаписывающая и звуковоспроизводящая аппаратура, аппаратура для записи и воспроизведения телевизионного изображения и звука, их части и принадлежности.

\section{Baikal Research Journal}


Как видно из табл. 4, снижение внешней торговли наблюдается у всех стран-участников ЕАЭС, что в свою очередь, сказывается на значительном сокращении поступлений в федеральный бюджет. Наибольшее падение внешней торговли наблюдается у Российской Федерации в 2016 г. - 135738,8 млн дол. США по 4 группам. Вторым направлением снижения внешней торговли было у Казахстана, по которому снижение составило 30242,6 млн. долл. США по 4 группам. Третьим направлением снижения внешней торговли было у Беларуси, но которому снижение составило 3816,1 млн. долл. США (по 4 группам).

Анализ финансовой статистики внешней торговли ЕАЭС позволил выявить актуальное состояние торговых отношений с третьими странами во внешней торговле [12]. На данный момент наблюдается снижение торговли стран-членов ЕАЭС с третьими странами, вследствие чего наблюдается снижение доходов интеграции в целом и поступлений в федеральный бюджет Российской Федерации в частности. Данное исследование позволило выявить группы товаров по ТН ВЭД ЕАЭС с наибольшим спадом объемов продажи, что в дальнейшем может быть использовано для более глубокого анализа. Анализируемый период отмечен неравномерностью динамики внешней торговли товарами [13]. В первую очередь возникает необходимость углубления кооперации и расширение импортозамещения, базирующегося на рациональном замещении импортной продукции из третьих стран конкурентоспособной продукцией, выпускаемой в государствах-членах ЕАЭС, и совместном освоении новой высокотехнологичной продукции. Такое взаимовыгодное многоаспектное сотрудничество необходимо нацелить на создание высокотехнологичной, инновационной и конкурентоспособной продукции по приоритетным видам экономической деятельности, по которым в данной статье был выявлен наибольший спад объемов продаж.

\section{Список использованной литературы}

1. Коновалова Г. Г. Статистика внешней торговли : учеб. пособие / Г. Г. Коновалова. Ярославль : ЯрГУ, 2006. - 160 с.

2. Буценко И. Н. Анализ внешней торговли Российской Федерации услугами / И. Н. Буценко, М. А. Махова // Экономические исследования и разработки. - 2017. № 2. - C. 151-161.

3. Трифонова Е. Ю. Оценка современного состояния и перспектив развития внешней торговли Российской Федерации / Е. Ю. Трифонова // Экономический анализ: теория и практика. - 2011. - № 1. - С. 2-10.

4. Дубинин М. В. Влияние евразийского экономического союза на развитие национальной экономики России / М. В. Дубинин // Тенденции и проблемы в экономике России: теоретические и практические аспекты : материалы Всерос. науч.-практ. конф. - Иркутск. : Изд-во БГУ, 2017. - С. 60-64.

5. Русакова Ю. Г. Взаимодействие между Китаем и странами-участницами Евразийского союза в энергетической сфере / Ю. Г. Русакова, Ю. А. Кафтулина // Вестник Пензенского государственного университета. - 2015. - № 2. - С. 53-58.

6. Масумова Н. Р. Внешняя торговля Турции и место России / Н. Р. Масумова // Мировое и национальное хозяйство. - 2016. - № 1 (36). - С. 17-28.

7. Воронцова Е. А. Либерализация торговли в рамках Евразийского экономического союза (на примере Соглашения ЕАЭС-Вьетнам) / Е. А. Воронцова // Московский журнал международного права. - 2015. - № 4 (100). - С. 103-115.

8. Бекбенбетова Б. Проблемы внешнеэкономической деятельности Казахстана в современных условиях / Б. Бекбенбетова, Ж . Б. Рахметулина // Вестник университета Туран. - 2017. - № 2 (74). - C. 25-31.

9. Королев В. И. Внешнеторговый менеджмент: содержание и инструменты / В. И. Королев, Е. Н. Королева // Российский внешнеэкономический вестник. - 2015. - № 1. C. $94-103$.

\section{Baikal Research Journal}

электронный научный журнал Байкальского государственного университета 
10. Килин В. В. Совершенствование таможенного администрирования и регулирования внешней торговли России в условиях ЕАЭС / В. В. Килин // Потребительский рынок Евразии: современное состояние, теория и практика в условиях евразийского экономического союза и ВТО : сб. ст. 3-й междунар. науч.-практ. конф. - Екатеринбург : Изд-во УрГЭУ, 2015. - C. 266-270.

11. Гильяно А. А. Механизм государственного регулирования внешней торговли в целях совершенствования взаимодействия стран ЕАЭС / А. А. Гильяно // Успехи современной науки и образования. - 2017. - Т. 5, № 4. - С. 67-70.

12. Михайлов М. В. Формирование общего финансового рынка ЕАЭС / М. В. Михайлов // Экономические науки. - 2016. — № 3 (136). - С. 92-95.

13. Спасских Н. А. ЕАЭС как пример регионального таможенного союза и его роль в мировой торговле товарами / Н. А. Спасских, Е. А. Аносов // Аллея науки. - 2017. № 8. - C. 153-156.

\section{References}

1. Konovalova G. G. Statistika vneshnei torgovli [Foreign trade statistics]. Jaroslavl State University Publ., 2006. 160 p.

2. Butsenko I. N., Makhova M. A. Analysis of the Russian Federation's foreign service trade. Ekonomicheskie issledovaniya $i$ razrabotki $=$ Economic Research and Developments, 2017, no. 2, pp. 151-161. (In Russian).

3. Trifonova E. Yu. Assessing the current state and prospects for the foreign trade development of the Russian Federation. Ekonomicheskii analiz: teoriya i praktika = Economic Analysis: Theory and Practice, 2011, no. 1, pp. 2-10. (In Russian).

4. Dubinin M. V. The Eurasian Economic Union influence on the Russian national economy development. Tendentsii $i$ problemy $v$ ekonomike Rossii: teoreticheskie $i$ prakticheskie aspekty [Tendencies and problems in the Russian economy: theoretical and practical aspects. Materials of All-Russian Research Conference]. Baikal State University Publ., 2017, pp. 60-64. (In Russian).

5. Rusakova Yu. G., Kaftulina Yu. A. Interaction between China and countries-participants of the Eurasian Union in energy sphere. Vestnik Penzenskogo gosudarstvennogo universiteta= Bulletin of Penza State University, 2015, no. 2, pp. 53-58. (In Russian).

6. Masumova N. R. Foreign trade of Turkey and role of Russia. Mirovoe $i$ natsional'noe khozyaistvo $=$ World and National Economy, 2016, no. 1 (36), pp. 17-28. (In Russian).

7. Vorontsova E. A. Trade liberalization in terms of the Eurasian Economic Union (in terms of the EAEU-Vietnam Agreement). Moskovskii zhurnal mezhdunarodnogo prava = Moscow Journal of International Law, 2015, no. 4 (100), pp. 103-115. (In Russian).

8. Bekbenbetova B., Rakhmetulina Zh. B. Problems of foreign economic activity of Kazakhstan in the current context. Vestnik universiteta "Turan" = Bulletin of "Turan» University, 2017, no. 2 (74), pp. 25-31. (In Russian).

9. Korolev V. I., Koroleva Ye. N. Foreign Trade Management: Content and Tools. Rossiiskii vneshneekonomicheskii vestnik = Bulletin of Russian Foreign Economy, 2015, no. 1, pp. 94-103. (In Russian).

10. Kilin V. V. Improving the customs administration and regulation of Russian foreign trade in terms of the UAEU. Potrebitel'skii rynok Evrazii: sovremennoe sostoyanie, teoriya $i$ praktika $v$ usloviyakh evraziiskogo ekonomicheskogo soyuza $i$ VTO [Consumer market of Eurasia: current state, theory and practice in the context of the Eurasian Economic Union and the WTO. $3^{\text {rd }}$ International Research Conference]. Ekaterinburg, Ural State Economic University, 2015, pp. 266-270. (In Russian).

11. Gilyano A A. Mechanism of foreign trade state regulation for improving the interaction of the EAEU countries. Uspekhi sovremennoi nauki i obrazovaniya = Achievements of Modern Science and Education, 2017, vol. 5, no. 4, pp. 67-70. (In Russian).

12. Mikhaylov M. V. Formation of the EAEU general financial market. Ekonomicheskie nauki = Economic Sciences, 2016, no. 3 (136), pp. 92-95. (In Russian).

13. Spasskikh N. A., Anosov E. A. EAEU as an example of regional customs union and its role in goods world trade. Alleya nauki=Alleya Nauki, 2017, no. 8, pp. 153-156. (In Russian).

\section{Baikal Research Journal}


Информация об авторе

Дубинин Максим Викторович - аспирант, кафедра налогов и таможенного дела, Байкальский государственный университет, 664003, г. Иркутск, ул. Ленина, 11, e-mail: maxdubinin@yandex.ru.

\section{Author}

Maxim V.Dubinin - PhD Student, Chair of Taxation and Customs, Baikal State University, 11 Lenin St., 664003, Irkutsk; e-mail: maxdubinin@yandex.ru

\section{Для цитирования}

Дубинин М. В. Ведение финансовой статистики внешней торговли Российской Федерации в условиях функционирования ЕАЭС / M. В. Дубинин // Baikal Research Journal. — 2017. - T. 8, № 4. — DOI : 10.17150/2411-6262.2017.8(4).2.

\section{For Citation}

Dubinin M.V. Mantaining the financial foreign trade statistics of the Russian Federation in terms of the EAEU functioning. Baikal Research Journal, 2017, vol. 8, no. 4. DOI: 10.17150/2411-6262.2017.8(4).2. (In Russian).

\section{Baikal Research Journal}

